\title{
Luteimicrobium subarcticum gen. nov., sp. nov., a new member of the suborder Micrococcineae
}

\author{
Correspondence \\ Moriyuki Hamada \\ hamada-moriyuki@nite.go.jp
}

\author{
Moriyuki Hamada, ${ }^{1}$ Misa Otoguro, ${ }^{1}$ Hideki Yamamura, ${ }^{2}$ \\ Tomohiko Tamura, ${ }^{1}$ Ken-ichiro Suzuki ${ }^{1}$ and Masayuki Hayakawa ${ }^{2}$ \\ ${ }^{1}$ NITE Biological Resource Center (NBRC), National Institute of Technology and Evaluation, \\ 2-5-8 Kazusakamatari, Kisarazu, Chiba 292-0818, Japan \\ ${ }^{2}$ Division of Applied Biological Sciences, Interdisciplinary Graduate School of Medicine and \\ Engineering, University of Yamanashi, 4-4-37 Takeda, Kofu, Yamanashi 400-8510, Japan
}

\begin{abstract}
A novel Gram-stain-positive bacterium, designated R19-04 ${ }^{\top}$, was isolated from a soil sample from Rishiri Island, Japan, and its taxonomic position was investigated by a polyphasic approach. Cells of strain R19-04 ${ }^{\top}$ exhibited a rod-coccus cycle. The peptidoglycan type of the isolate was $A 4 \alpha$; lysine was the diagnostic diamino acid. The predominant menaquinone was MK-8 $\left(\mathrm{H}_{2}\right)$ and the major fatty acid was anteiso- $\mathrm{C}_{15: 0}$. The polar lipids were diphosphatidylglycerol and phosphatidylglycerol. The DNA G +C content was 72.9 mol\%. Phylogenetic analysis based on $16 \mathrm{~S}$ rRNA gene sequence comparisons revealed that strain R19-0 $4^{\top}$ represented a novel member of the suborder Micrococcineae. Its nearest phylogenetic neighbours were the members of the genus Oerskovia, with 16S rRNA gene sequence similarity of 97.0-97.1\%. However, strain R19-04 ${ }^{\top}$ was clearly distinguishable from members of the genus Oerskovia and phylogenetically related genera in terms of chemotaxonomic characteristics. On the basis of the chemotaxonomic and phylogenetic characteristics, a novel genus and species are proposed, Luteimicrobium subarcticum gen. nov., sp. nov. The type strain of Luteimicrobium subarcticum is R19-04 ${ }^{\top}\left(=\right.$ NBRC $105647^{\top}=$ DSM $\left.22413^{\top}\right)$.
\end{abstract}

The suborder Micrococcineae was first proposed by Stackebrandt et al. (1997) and its description was later emended by Zhi et al. (2009). This suborder is one of the most studied taxa in the class Actinobacteria. While isolating bacteria from subarctic and subtropical islands, we isolated a novel actinobacterium (strain R19-0 $4^{\mathrm{T}}$ ) from a soil sample from Rishiri Island (subarctic), Hokkaido, Japan, using the rehydration and centrifugation method (Hayakawa et al., 2000) and humic acid-vitamin (HV) agar (Hayakawa \& Nonomura, 1987). Comparative 16S rRNA gene sequence analysis revealed that the isolate is a member of the suborder Micrococcineae. The objective of this study was to determine the taxonomic position of strain R19-0 $4^{\mathrm{T}}$ by using a polyphasic approach.

Maltose-Bennett's medium [NBRC medium 231; containing $0.1 \%$ yeast extract (Difco), $0.1 \%$ beef extract (Difco), $0.2 \% \mathrm{NZ}$ Amine type A (Wako), $1.0 \%$ maltose; $2.0 \%$ agar if required; $\mathrm{pH}$ 6.0] was used for general laboratory cultivation, morphological studies and determination of optimal growth parameters. Colony appearance and pigment production were examined following growth at $28{ }^{\circ} \mathrm{C}$ for 3 days on several culture media: NBRC medium

The GenBank/EMBL/DDBJ accession number for the 16S rRNA gene sequence of strain R19-04 ${ }^{\top}$ is AB489904.
231, R2A agar (Difco), trypticase soy agar (TSA; Difco), brain heart infusion agar (BHI; Difco) and Todd-Hewitt broth (Difco) supplemented with $1.5 \%$ agar. Cell morphology was investigated by examining cells from cultures over a whole growth cycle (up to 5 days) under a light microscope (BX-51; Olympus) and a scanning electron microscope (JSM-6060; JEOL). Cell motility was determined by observing cells suspended in saline solution under a light microscope. Growth under anaerobic conditions was determined by incubating in an anaerobic chamber with an $\mathrm{O}_{2}$-absorbing and $\mathrm{CO}_{2}$-generating agent (AnaeroPack; Mitsubishi Gas Chemical). Growth parameters (temperature, $\mathrm{pH}$ and $\mathrm{NaCl}$ tolerance) were determined by measuring the turbidity (at $610 \mathrm{~nm}$ ) of $5 \mathrm{ml}$ of the culture medium in test tubes after 1-2 days of incubation at $28{ }^{\circ} \mathrm{C}$. The temperature range and optimum temperature for growth were determined by incubating the cultures at $5,10,15,20,25,28,35,45$ and $60{ }^{\circ} \mathrm{C}$. The $\mathrm{pH}$ range and optimum $\mathrm{pH}$ for growth were established by using a medium adjusted to $\mathrm{pH} 4-10$ with either $4 \mathrm{M} \mathrm{HCl}$ or $5 \mathrm{M} \mathrm{KOH}$ and incubation at $28{ }^{\circ} \mathrm{C}$. $\mathrm{NaCl}$ tolerance and optimum concentration $(1,3,5,7,10$ and $15 \%$, w/v) were determined at $28{ }^{\circ} \mathrm{C}$. Gram staining was performed by using Hucker's modification (Gerhardt et al., 1994). DNase test agar (Difco) was used for the DNase assay. Other physiological and biochemical tests were performed using 
API ZYM, API Coryne, API 20E and API 50CH systems (bioMérieux) according to the manufacturer's instructions. Biomass for chemotaxonomic and molecular systematic studies was prepared by growing the strain in shake flasks containing NBRC medium 231 for $48 \mathrm{~h}$ at $28{ }^{\circ} \mathrm{C}$ at 100 r.p.m.

Strain R19-04 ${ }^{\mathrm{T}}$ formed yellow, circular, rough colonies that were approximately $0.2 \mathrm{~mm}$ in diameter on NBRC medium 231 after 3 days incubation at $28{ }^{\circ} \mathrm{C}$. Growth also occurred on R2A, TSA, BHI and Todd-Hewitt agar. Pigment production was not observed. The cells of the strain were Gram-stain-positive, aerobic, non-motile and non-sporulating and exhibited a rod-coccus cycle. Cells of exponentially growing cultures were irregular rods $(0.5-$ $0.7 \times 1.0-3.0 \mu \mathrm{m}$ ), while stationary-phase cells were cocci (approximately $0.7 \mu \mathrm{m}$ in diameter). Growth occurred at $10-35{ }^{\circ} \mathrm{C}$ and no growth was observed at 5,45 or $60{ }^{\circ} \mathrm{C}$. The $\mathrm{pH}$ range for growth was $\mathrm{pH}$ 5.0-9.0. Optimal growth was noted at $28{ }^{\circ} \mathrm{C}$ and $\mathrm{pH}$ 6.0. Strain R $19-04^{\mathrm{T}}$ exhibited good growth with $\mathrm{NaCl}$ concentrations of $0-3 \%$ and moderate growth with $5 \%$; no growth was observed with 7 , 10 or $15 \% \mathrm{NaCl}$. Optimal growth was noted with $1 \%$ $\mathrm{NaCl}$. Growth under anaerobic conditions was not observed. The results of other physiological and biochemical analyses have been summarized in the species description.

Cell-wall samples were prepared from approximately $1 \mathrm{~g}$ wet cells by mechanical disruption with an ultrasonic oscillator and were purified as described by Schleifer \& Kandler (1972). The amino acids in cell-wall hydrolysates were analysed using the methods described by Tamura et al. (1994). The amino acid isomers in cell-wall hydrolysates were examined using the method described by Nozawa et al. (2007) with the following modifications. Separation of 1-fluoro-2,4-dinitrophenyl-5-L-leucinamide and 1-fluoro2,4-dinitrophenyl-5-D-leucinamide derivatives of amino acids was performed using a model LC-20AB HPLC apparatus (Shimadzu) equipped with a Wakopak Wakosil PTC column (Wako). Cellular fatty acids were processed and analysed as methyl esters, using the protocol of the MIDI Sherlock Microbial Identification System (Sasser, 1990). Menaquinones were extracted from a $300 \mathrm{mg}$ freeze-dried cell sample and analysed according to the method described by Tamura et al. (1994). Polar lipids and the DNA G $+\mathrm{C}$ content were also analysed as described by Tamura et al. (1994).

Purified peptidoglycan of strain R19-04 ${ }^{\mathrm{T}}$ contained alanine, glutamic acid and lysine in a molar ratio of $2.0: 2.0: 0.7$. Enantiomeric analysis of the peptidoglycan amino acids revealed the presence of D-Ala, L-Ala, D-Glu and L-Lys. These data indicated that the cell-wall peptidoglycan of strain R19-04 ${ }^{\mathrm{T}}$ is of the A4 $\alpha$ type (Schleifer \& Kandler, 1972) with an L-Lys $\leftarrow$ D-Glu interpeptide bridge. The major cellular fatty acid was anteiso$\mathrm{C}_{15: 0}(71.4 \%)$, while minor components were $\mathrm{C}_{16: 0}$ $(10.9 \%), \quad$ anteiso- $\mathrm{C}_{17: 0} \quad(8.0 \%), \quad$ iso- $\mathrm{C}_{16: 0} \quad(5.1 \%)$, iso- $\mathrm{C}_{15: 0}(2.3 \%), \mathrm{C}_{14: 0}(1.3 \%)$ and iso- $\mathrm{C}_{14: 0}(1.0 \%)$. The polar lipids were diphosphatidylglycerol and phosphatidylglycerol. Glycolipids were not detected. The predominant menaquinone was $\mathrm{MK}-8\left(\mathrm{H}_{2}\right)$; MK-9 $\left(\mathrm{H}_{2}\right)$ was present as a minor component. The DNA $\mathrm{G}+\mathrm{C}$ content was $72.9 \mathrm{~mol} \%$.

PCR amplification of the 16S rRNA gene of strain R19-04 ${ }^{\mathrm{T}}$ was performed as described by Tamura \& Hatano (2001). This gene was directly sequenced using a BigDye Terminator version 3.1 Cycle Sequencing kit (Applied Biosystems) and an automatic DNA sequencer (ABI Prism 3730 Genetic Analyzer; Applied Biosystems). The almostcomplete 16S rRNA gene sequence determined in this study was aligned with reference sequences of the genera Oerskovia (Prauser et al., 1970) and Cellulosimicrobium (Schumann et al., 2001) and some related taxa by using the CLUSTAL x program (Thompson et al., 1997). A phylogenetic tree was constructed by using the neighbour-joining (Saitou \& Nei, 1987) and maximum-likelihood methods (Felsenstein, 1981). The resultant neighbour-joining tree topology was evaluated by bootstrap analysis based on 1000 replicates (Felsenstein, 1985).

Phylogenetic analysis performed on the basis of the $16 \mathrm{~S}$ rRNA gene sequence revealed that strain R19- $04^{\mathrm{T}}$ belonged to the suborder Micrococcineae. However, strain R19-0 ${ }^{\mathrm{T}}$ did not form a reliable clade with any members of the suborder Micrococcineae. The position of strain R19-04 relative to its phylogenetic neighbours is shown in Fig. 1. The highest $16 \mathrm{~S}$ rRNA gene sequence similarity values were obtained with members of the genera Oerskovia (97.097.1\%), Cellulosimicrobium (96.3-97.1\%), Cellulomonas (95.1-96.7\%) and Isoptericola (95.6-96.3\%).

The predominant menaquinone of strain $\mathrm{R} 19-04^{\mathrm{T}}$ was different from those of phylogenetically related taxa. The predominant menaquinone of the isolate was MK$8\left(\mathrm{H}_{2}\right)$. In contrast, the predominant menaquinone of the genera Oerskovia, Cellulosimicrobium, Cellulomonas and Isoptericola is reported to be MK- $9\left(\mathrm{H}_{4}\right)$. In addition, strain R19-04 ${ }^{\mathrm{T}}$ possessed a peptidoglycan interpeptide bridge comprising L-Lys $\leftarrow \mathrm{D}-$ Glu. This structure has not been reported for members of the genera Oerskovia and Cellulosimicrobium. These data indicated that the chemotaxonomic characteristics of strain R19-04 ${ }^{\mathrm{T}}$ were distinct from those of its phylogenetic neighbours (Table 1). On the basis of the chemotaxonomic and phylogenetic characteristics, strain R19-04 ${ }^{\mathrm{T}}$ represents a novel genus and species, for which the name Luteimicrobium subarcticum gen. nov., sp. nov. is proposed.

The results of the phylogenetic analysis of the 16S rRNA gene sequence suggested that the genus Luteimicrobium is related to the families Cellulomonadaceae and Promicromonosporaceae. However, the new genus did not form a reliable clade with any members of these families. Hence, the genus Luteimicrobium cannot be accommodated in either of these families at this time. Further studies are required in order to elucidate the taxonomic position of the new genus. 


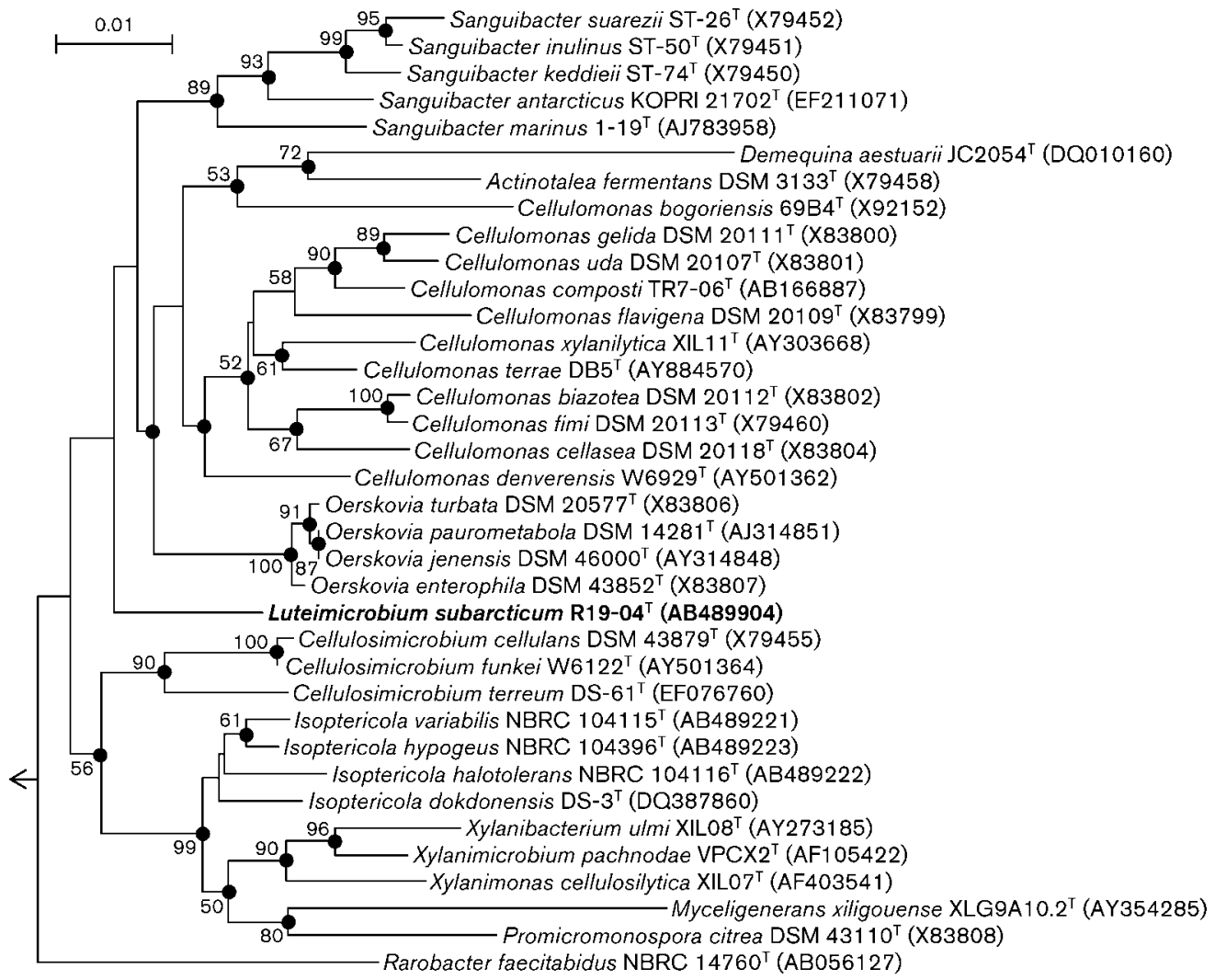

Fig. 1. Phylogenetic tree derived from 16S rRNA gene sequences of strain $R 19-04^{\top}$ and its taxonomic neighbours, constructed with the neighbour-joining method. The sequence of Brevibacterium linens DSM $20425^{\top}$ (GenBank accession no. X77451) was used as the outgroup (not shown). Bootstrap values ( $>50 \%$ ) based on 1000 replicates are shown at branch nodes. Filled circles indicate that the corresponding nodes were also recovered in the tree generated with the maximumlikelihood algorithm. Bar, 0.01 substitutions per nucleotide position.

Table 1. Differential chemotaxonomic characteristics of strain R19-04 ${ }^{\top}$ and the genera Oerskovia, Cellulosimicrobium, Cellulomonas and Isoptericola

Data for reference genera were taken from previous studies (Schumann et al., 2001; Stackebrandt et al., 2004, 2006; Yoon et al., 2006, 2007). ND, No data available.

\begin{tabular}{|c|c|c|c|c|c|}
\hline Characteristic & R19-04 ${ }^{\mathrm{T}}$ & Oerskovia & Cellulosimicrobium & Cellulomonas & Isoptericola \\
\hline Peptidoglycan type & $\mathrm{A} 4 \alpha$ & $\mathrm{A} 4 \alpha$ & $\mathrm{A} 4 \alpha$ & $\mathrm{A} 4 \beta$ & $\mathrm{A} 4 \alpha$ \\
\hline Diamino acid & L-Lys & L-Lys & L-Lys & L-Orn & L-Lys \\
\hline Interpeptide bridge & L-Lys-D-Glu & $\begin{array}{l}\text { L-Thr-D-Asp or } \\
\text { L-Thr-D-Glu }\end{array}$ & D-Ser-D-Asp or L-Thr-D-Asp & D-Asp or D-Glu & D-Asp or D-Glu \\
\hline Major menaquinone(s) & $\mathrm{MK}-8\left(\mathrm{H}_{2}\right)$ & MK-9 $\left(\mathrm{H}_{4}\right)$ & MK-9 $\left(\mathrm{H}_{4}\right)$ & MK-9 $\left(\mathrm{H}_{4}\right)$, MK-8 $\left(\mathrm{H}_{4}\right)$ & MK-9 $\left(\mathrm{H}_{4}\right)$ \\
\hline Major fatty acid(s)* & ai- $\mathrm{C}_{15: 0}$ & ai- $C_{15: 0}, C_{16: 0}$ & ai- $C_{15: 0}, \mathrm{i}-\mathrm{C}_{15: 0}$ & ai- $C_{15: 0}, C_{14: 0}$ & ai- $C_{15: 0}, \mathrm{i}-\mathrm{C}_{15: 0}$ \\
\hline Polar lipids $\dagger$ & PG, DPG & PG, DPG, PI & $\mathrm{ND}$ & PG, DPG, PI, PGL & PG, DPG, PI, PI \\
\hline DNA G $+\mathrm{C}$ content $(\mathrm{mol} \%)$ & 72.9 & $70.5-75.0$ & $72.9-74.5$ & $69-76$ & $70-74$ \\
\hline
\end{tabular}

*ai, Anteiso-branched; i, iso-branched.

$\nmid$ DPG, Diphosphatidylglycerol; PG, phosphatidylglycerol; PGL, unidentified phosphoglycolipid; PI, phosphatidylinositol; PL, unidentified phospholipid. 


\section{Description of Luteimicrobium gen. nov.}

Luteimicrobium (Lu.te.i.mi.cro'bi.um. L. adj. luteus yellow; N.L. neut. n. microbium microbe; N.L. neut. n. Luteimicrobium a yellow microbe).

Cells exhibit a rod-coccus cycle and are Gram-stainpositive, aerobic and non-sporulating. The cell-wall peptidoglycan is of the A4 $\alpha$ type. The predominant menaquinone is $\mathrm{MK}-8\left(\mathrm{H}_{2}\right)$ and the major polar lipids are diphosphatidylglycerol and phosphatidylglycerol. The major cellular fatty acid is anteiso- $\mathrm{C}_{15: 0}$. Phylogenetically, the genus Luteimicrobium belongs to the suborder Micrococcineae within the order Actinomycetales. The type species is Luteimicrobium subarcticum.

\section{Description of Luteimicrobium subarcticum sp. nov.}

Luteimicrobium subarcticum (sub.arc'ti.cum. L. prep. sub low, below, under; L. neut. adj. arcticum northern, arctic; N.L. neut. adj. subarcticum subarctic, referring to the isolation of the type strain from the subarctic Rishiri Island).

Displays the following properties in addition to those given for the genus. Rods are $0.5-0.7 \times 1.0-3.0 \mu \mathrm{m}$ and cocci are approximately $0.7 \mu \mathrm{m}$ in diameter. Cells are non-motile. Colonies are circular, rough and yellow. Catalase-positive and oxidase-negative. Growth occurs with $\mathrm{NaCl}$ concentrations of $0-5 \%$ but not with 7,10 or $15 \%$; optimal $\mathrm{NaCl}$ concentration is $1 \%$. Grows at $10-35{ }^{\circ} \mathrm{C}$ (optimum $28{ }^{\circ} \mathrm{C}$ ) and $\mathrm{pH}$ 5.0-9.0 (optimum $\mathrm{pH}$ 6.0). Acid is produced from $\mathrm{N}$-acetylglucosamine, amygdalin, L-arabinose, arbutin, cellobiose, D-fructose, D-galactose, gentiobiose, D-glucose, maltose, D-mannose, sucrose and D-xylose. Leucine arylamidase, $\beta$-galactosidase, $\alpha$ - and $\beta$-glucosidases and $N$-acetyl- $\beta$-glucosaminidase are present, but alkaline phosphatase, esterase lipase (C8), lipase (C4), valine arylamidase, cysteine arylamidase, trypsin, chymotrypsin, acid phosphatase, phosphohydrolase, $\alpha$-galactosidase, $\beta$-glucuronidase, $\alpha$-mannosidase, $\alpha$-fucosidase, pyrazinamidase, pyrrolidonyl arylamidase, arginine dihydrolase, lysine and ornithine decarboxylases and tryptophan deaminase are absent. $\mathrm{H}_{2} \mathrm{~S}$ and indole are not produced. Aesculin is hydrolysed, but gelatin, urea and DNA are not hydrolysed. Nitrate is reduced. The interpeptide bridge of the cell-wall peptidoglycan is L-Lys $\leftarrow$ D-Glu. MK- $9\left(\mathrm{H}_{2}\right)$ is present as a minor component. $C_{16: 0}$, anteiso- $C_{17: 0}$, iso- $C_{16: 0}$, iso- $\mathrm{C}_{15: 0}, \mathrm{C}_{14: 0}$ and iso- $\mathrm{C}_{14: 0}$ are found in minor amounts. The DNA G $+\mathrm{C}$ content of the type strain is $72.9 \mathrm{~mol} \%$.

The type strain R19-04 ${ }^{\mathrm{T}}\left(=\mathrm{NBRC} 105647^{\mathrm{T}}=\mathrm{DSM} 22413^{\mathrm{T}}\right)$ was isolated from a soil sample from Rishiri Island, Japan.

\section{Acknowledgements}

This study was supported in part by a research grant from the Institute for Fermentation, Osaka (IFO).

\section{References}

Felsenstein, J. (1981). Evolutionary trees from DNA sequences: a maximum likelihood approach. J Mol Evol 17, 368-376.

Felsenstein, J. (1985). Confidence limits on phylogenies: an approach using the bootstrap. Evolution 39, 738-791.

Gerhardt, P., Murray, R. G. E., Wood, W. A. \& Krieg, N. R. (editors) (1994). Methods for General and Molecular Bacteriology. Washington, DC: American Society for Microbiology.

Hayakawa, M. \& Nonomura, H. (1987). Humic acid-vitamin agar, a new medium for the selective isolation of soil actinomycetes. J Ferment Technol 65, 501-509.

Hayakawa, M., Otoguro, M., Takeuchi, T., Yamazaki, T. \& limura, Y. (2000). Application of a method incorporating differential centrifugation for selective isolation of motile actinomycetes in soil and plant litter. Antonie van Leeuwenhoek 78, 171-185.

Nozawa, Y., Sakai, N., Arai, K., Kawasaki, Y. \& Harada, K. (2007). Reliable and sensitive analysis of amino acids in the peptidoglycan of actinomycetes using the advanced Marfey's method. J Microbiol Methods 70, 306-311.

Prauser, H., Lechevalier, M. P. \& Lechevalier, H. A. (1970). Description of Oerskovia gen. n. to harbor Ørskov's motile Nocardia. Appl Microbiol 19, 534.

Saitou, N. \& Nei, M. (1987). The neighbor-joining method: a new method for reconstructing phylogenetic trees. Mol Biol Evol 4, 406425.

Sasser, M. (1990). Identification of bacteria by gas chromatography of cellular fatty acids, MIDI Technical Note 101. Newark, DE: MIDI Inc.

Schleifer, K. H. \& Kandler, O. (1972). Peptidoglycan types of bacterial cell walls and their taxonomic implications. Bacteriol Rev 36, 407-477.

Schumann, P., Weiss, N. \& Stackebrandt, E. (2001). Reclassification of Cellulomonas cellulans (Stackebrandt and Keddie 1986) as Cellulosimicrobium cellulans gen. nov., comb. nov. Int J Syst Evol Microbiol 51, 1007-1010.

Stackebrandt, E., Rainey, F. A. \& Ward-Rainey, N. L. (1997). Proposal for a new hierarchic classification system, Actinobacteria classis nov. Int J Syst Bacteriol 47, 479-491.

Stackebrandt, E., Schumann, P. \& Cui, X.-L. (2004). Reclassification of Cellulosimicrobium variabilis gen. nov., comb. nov. Int J Syst Evol Microbiol 54, 685-688.

Stackebrandt, E., Schumann, P. \& Prauser, H. (2006). The family Cellulomonadaceae. In The Prokaryotes: a Handbook on the Biology of Bacteria, 3rd edn, vol. 3, pp. 983-1001. Edited by M. Dworkin, S. Falkow, E. Rosenberg, K. H. Schleifer \& E. Stackebrandt. New York: Springer.

Tamura, T. \& Hatano, K. (2001). Phylogenetic analysis of the genus Actinoplanes and transfer of Actinoplanes minutisporangius Ruan et al. 1986 and 'Actinoplanes aurantiacus' to Cryptosporangium minutisporangium comb. nov. and Cryptosporangium aurantiacum sp. nov. Int $J$ Syst Evol Microbiol 51, 2119-2125.

Tamura, T., Nakagaito, Y., Nishi, T., Hasegawa, T., Stackebrandt, E. \& Yokota, A. (1994). A new genus of the order Actinomycetales, Couchioplanes gen. nov., with descriptions of Couchioplanes caeruleus (Horan and Brodsky 1986) comb. nov. and Couchioplanes caeruleus subsp. azureus subsp. nov. Int J Syst Bacteriol 44, 193203.

Thompson, J. D., Gibson, T. J., Plewniak, F., Jeanmougin, F. \& Higgins, D. G. (1997). The CLUSTAL_X windows interface: flexible strategies for multiple sequence alignment aided by quality analysis tools. Nucleic Acids Res 25, 4876-4882. 
Yoon, J.-H., Schumann, P., Kang, S.-J., Jung, S.-Y. \& Oh, T.-K. (2006). Isoptericola dokdonensis sp. nov., isolated from soil. Int J Syst Evol Microbiol 56, 2893-2897.

Yoon, J.-H., Kang, S.-J., Schumann, P. \& Oh, T.-K. (2007). Cellulosimicrobium terreum sp. nov., isolated from soil. Int $J$ Syst Evol Microbiol 57, 2493-2497.
Zhi, X.-Y., Li, W.-J. \& Stackebrandt, E. (2009). An update of the structure and 16S rRNA gene sequence-based definition of higher ranks of the class Actinobacteria, with the proposal of two new suborders and four new families and emended descriptions of the existing higher taxa. Int J Syst Evol Microbiol 59, 589608. 